\title{
Short-term effects on soil properties and wheat production from secondary paper sludge application on two Mediterranean agricultural soils
}

\author{
J. Rato Nunes $^{\mathrm{a}, *}$, F. Cabral $^{\mathrm{b}}$, A. López-Piñeiro ${ }^{\mathrm{c}}$ \\ ${ }^{a}$ Escola Superior Agrária de Elvas, Apartado 254, 7350 Elvas, Portugal \\ b Instituto Superior de Agronomía, Departamento de Química Agrícola, Tapada de Ajuda, 1300 Lisboa, Portugal \\ c Área de Edafología y Química Agrícola, Facultad de Ciencias, Universidad de Extremadura, Avda de Elvas S/N, 06071 Badajoz, Spain
}

Received 22 February 2007; received in revised form 4 September 2007; accepted 10 September 2007

Available online 25 October 2007

\begin{abstract}
This study was conducted under greenhouse conditions to evaluate the potential use of SPS as a fertilizer, amendment and/or liming agent for wheat (Triticum aestivum L.). Two representative Mediterranean agricultural soils, a Cambic Arenosol (cmAR) and a Cromic Cambisol (crCM) were used. Treatments included four sludge rates ranging from 0 to $40 \mathrm{~g} \mathrm{~kg}^{-1}$ (equivalent of 0 , 38, 88 and $120 \mathrm{Mg} \mathrm{ha}^{-1}$ ). A significant increment in soil $\mathrm{pH}$, organic carbon, $\mathrm{N}$ total, available $\mathrm{P}$ and exchangeable $\mathrm{K}$ were observed in both soils. Sludge application significantly increased $\mathrm{N}$ and decreased $\mathrm{Zn}, \mathrm{Mn}$ and $\mathrm{Cu}$ concentrations in wheat. Wheat grain yields were reduced by $33 \%$ and $37 \%$ when $120 \mathrm{Mg}$ SPS ha $^{-1}$ was applied to cmAR and crCM soils, respectively, due apparently to unavailability of Mg. However, straw yields, with much lower Mg requirements, increased significantly with SPS rates. Secondary pulp mill sludge seems to be a potential source of organic matter, N, P, K and a potential soil amendment liming agent for acid soils, when appropriate supplemental fertilizer was provided. For grain crops grown in these soils, addition of $\mathrm{Mg}$ is required for proper nutrient balance.
\end{abstract}

(C) 2007 Elsevier Ltd. All rights reserved.

Keywords: Mediterranean soils; Secondary paper mill sludge; Wheat fertilization

\section{Introduction}

The wood pulping and production of the paper products generate a considerable amount of pollutants. In the beginning of the Nineties of the previous century the United Kingdom paper mills produce a total of 250,000 dry tons of waste sludge per year (Phillips et al., 1997), while in 1995 the US pulp and paper industry produced approximately 5.3 million metric tons of paper mill wastewater treatment residuals (Feldkinchner et al., 2003). The pulp and paper industry is considered as the third largest polluter in the United States and has been estimated that this

\footnotetext{
* Corresponding author. Tel.: +351 268628528; fax: +351 268628529.

E-mail address: ratonunes@esaelvas.pt (J. Rato Nunes).
}

industry is responsible for $50 \%$ of all wastes dumped into Canadás waters (Pokhrel and Viraraghavan, 2004). In Portugal, which has one-third of its mainland in forest, the paper industry has grown considerably and currently generates approximately $1,300,000 \mathrm{Mg} \mathrm{yr}^{-1}$ of pulp and paper mill sludge, with severe environmental problems (Santos, 2003). Disposal of this material presents a problem for the mill (Battaglia et al., 2007; Calace et al., 2005; Mahmood and Elliot, 2006). Some of it may be incinerated, but the high water content impedes an efficient combustion. Disposal by land filling, the most common disposal method, is costly and faces increasingly stringent environmental regulations (Feldkinchner et al., 2003).

Mediterranean soils, due to the natural characteristics of this region climate (warm and dry summers with a prolonged drought, and heavy rainfall during autumn and winter) and inadequate land management have led to a 
reduction in the organic matter content of soils (Madrid et al., 2007). This situation has a direct negative influence on the physical, chemical and biological properties of the soils and causes structural degradation and an eventual loss of fertility (Wei and Liu, 2005). Maintaining adequate organic content is necessary for maintaining soil fertility and sustainable crop growth (Madrid et al., 2007; Rotenberg et al., 2005).

Using pulp mill sludges, with their high organic matter content and low concentrations of trace metals and organic pollutants, as a soil amendment on farmland is an attractive alternative because it allows for some cost recovery, improves soil physical properties and recycles the carbon into the soil (Calace et al., 2005; Carpenter and Fernández, 2000; Gagnon et al., 2001; Mahmood and Elliot, 2006). In fact, a large number of researchers have reported substantial benefits to soil fertility and crop yields of low-carbon soils, such as the majority of Mediterranean soils, from amendment, at acceptable loading rates, with pulp mill solids (Leon et al., 2006; Levy and Taylor, 2003), namely, pulp mill residuals added to soil can significantly increase the amounts of soil organic matter (Rotenberg et al., 2005), providing a whole array of nutrients to soils (Feldkinchner et al., 2003), decrease soil acidification (Battaglia et al., 2007; Nunes et al., 2002), decrease of soil metal pollution (Battaglia et al., 2007; Calace et al., 2005), increasing beneficial soil organisms and reducing plant pathogens, increase water and nutrient retention (Foley and Cooperband, 2002) and improve the soil's ability to suppress crop diseases (Leon et al., 2006; Madrid et al., 2007; Rotenberg et al., 2005), providing an interesting solution to soil degradation (Levy and Taylor, 2003; Tejada et al., 2007; Xiao et al., 2007). However paper mill sludge C:N ratios can be quite high (e.g. 100-300:1) for primary sludges, representing $40 \%$ of the total amount of sludge generate by the industry, or very low for secondary sludges, since nitrogen and phosphorus are typically added to increase microbial decomposition (Vance, 2000). Land applications of sludges with low $\mathrm{N}$ concentration may lead to a temporary immobilization of soil N. Conversely, large amounts of $\mathrm{N}$ applied with paper mill sludge could potentially cause nitrate leaching (Feldkinchner et al., 2003).
Several studies have investigated the use of primary and combined primary/secondary sludges (the largest proportion of paper mill sludges generated are mixtures of primary and secondary sludges - about 54\% (Vance, 2000)) as a source of organic material (among others - Leon et al., 2006; Madrid et al., 2007; Rotenberg et al., 2005; Tejada et al., 2007; Xiao et al., 2007), but relatively very few have used secondary sludges in this regard, as Cordovil et al. (2007), Feldkinchner et al. (2003) or Nunes et al. (2002) still fewer studies have been carried out under Mediterranean soil conditions, as Cabral and Vasconcelos (1993), Cordovil et al. (2007) or Nunes et al. (2002).

The objectives of this study were to investigate (1) the chemical properties of two Mediterranean agricultural soils amended with various rates of secondary paper mill sludge and (2) the yield and elemental concentrations of wheat (Triticum aestivum L.) grown on these soils in a greenhouse.

\section{Methods}

\subsection{Bulk soil and sludge}

The study was conducted with two representative Mediterranean agricultural soils from Portugal: a Cambic Arenosol (cmAR) and a sandy loam Cromic Cambisol (crCM) (FAO, 2006). Selected soil properties of both soils are given in Table 1. Bulk samples were collected from surface $(0-30 \mathrm{~cm})$ horizon, air-dried, passed through a $2 \mathrm{~mm}$ sieve, and analyzed as described below. The pulp mill sludge (SPS) used in this trial was obtained at the Portucel pulp industry-Setúbal (Portugal) wastewater treatment plant and was generated during the secondary aeration process. A sample of this sludge was air-dried and analyzed as described below. Characteristics of the secondary pulp mill sludge applied are summarized in Table 2.

\subsection{Experimental treatments and wheat cropping}

Each soil was mixed with four rates of sludge $0,38,88$ and $120 \mathrm{Mg} \mathrm{ha}^{-1}$ (equivalent of $0-40 \mathrm{~g} \mathrm{~kg}^{-1}$ ) and placed in $20 \mathrm{~cm}$ diameter plastic pots, $7.8 \mathrm{~L}$ in volume. The pots

Table 1

Selected initial properties of the unamended soils

\begin{tabular}{llccc}
\hline Chemical properties & Unit & Cambic arenosol & Cromic cambisol & Threshold levels \\
\hline Organic carbon & $\mathrm{g} \mathrm{kg}^{-1}$ & $5.42 \pm 0.2$ & $3.10 \pm 0.3$ & $2.9-8.7$ \\
pH (1:5) & & $6.40 \pm 0.1$ & $5.00 \pm 0.2$ & $4.5-9.5$ \\
Total N & $\mathrm{g} \mathrm{kg}^{-1}$ & $0.42 \pm 0.1$ & $0.39 \pm 0.1$ & $0.5-4.1$ \\
$\mathrm{NO}_{3}-\mathrm{N}$ & $\mathrm{mg} \mathrm{kg}^{-1}$ & $15.81 \pm 1.7$ & $24.05 \pm 2.1$ & - \\
$\mathrm{NH}_{4}-\mathrm{N}$ & $\mathrm{mg} \mathrm{kg}^{-1}$ & $7.21 \pm 0.8$ & $4.56 \pm 0.6$ & - \\
Egner-Riehm P & $\mathrm{mg} \mathrm{kg}^{-1}$ & $25.00 \pm 3.0$ & $18.00 \pm 3.1$ & $11-100$ \\
Egner-Riehm K & $\mathrm{mg} \mathrm{kg}^{-1}$ & $55.00 \pm 3.8$ & $134.00 \pm 4.2$ & $11-110$ \\
CEC $^{\text {a }}$ & $\mathrm{cmol}_{\mathrm{c} \mathrm{kg}}^{-1}$ & $3.73 \pm 0.3$ & $9.09 \pm 0.7$ & - \\
PBS $^{\text {b }}$ & $\%$ & $65.14 \pm 4.1$ & $58.26 \pm 4.2$ & - \\
\hline
\end{tabular}

Means and standard deviation are calculated from five replicates.

${ }^{\text {a }} \mathrm{CEC}=$ cation exchange capacity.

${ }^{\mathrm{b}} \mathrm{PBS}=$ percent base saturation. 
Table 2

Initial chemical characteristics of the unamended paper mill sludge

\begin{tabular}{llll}
\hline Chemical properties & Unit & SPS & Guidelines $^{\mathrm{a}}$ \\
\hline Moisture content & $\%$ & $84.20 \pm 3$ & \\
Organic C & $\mathrm{g} \mathrm{kg}^{-1}$ & $283.10 \pm 15$ & \\
pH & & $7.80 \pm 0.3$ & \\
Total N & $\mathrm{g} \mathrm{kg}^{-1}$ & $26.70 \pm 1.1$ & \\
$\mathrm{~K}$ & $\mathrm{~g} \mathrm{~kg}^{-1}$ & $0.90 \pm 0.1$ & \\
$\mathrm{P}$ & $\mathrm{g} \mathrm{kg}^{-1}$ & $15.30 \pm 0.7$ & \\
$\mathrm{Na}$ & $\mathrm{g} \mathrm{kg}^{-1}$ & $6.00 \pm 0.4$ & \\
$\mathrm{Ca}$ & $\mathrm{g} \mathrm{kg}^{-1}$ & $25.60 \pm 1.2$ & \\
$\mathrm{Mg}$ & $\mathrm{g} \mathrm{kg}^{-1}$ & $2.60 \pm 0.3$ & \\
$\mathrm{Fe}$ & $\mathrm{g} \mathrm{kg}^{-1}$ & $3.05 \pm .0 .1$ & 2000 \\
$\mathrm{Cu}$ & $\mathrm{mg} \mathrm{kg}^{-1}$ & $22.75 \pm 3.0$ & 1500 \\
$\mathrm{Mn}$ & $\mathrm{g} \mathrm{kg}^{-1}$ & $4.03 \pm 0.3$ & 10,000 \\
$\mathrm{Zn}$ & $\mathrm{mg} \mathrm{kg}^{-1}$ & $58.50 \pm 7.0$ & \\
$\mathrm{C}: \mathrm{N}$ & & 10.60 & \\
$\mathrm{C}: \mathrm{P}$ & & 18.49 & \\
$\mathrm{Ca}: \mathrm{Mg}$ & & 9.84 & \\
\hline
\end{tabular}

Means and standard deviation are calculated from five replicates.

a Guidelines for agricultural utilization of sludges (Bowie and Thornton, 1985).

were fertilized with $140 \mathrm{mg} \mathrm{N} \mathrm{kg}\left(\mathrm{NH}_{4} \mathrm{SO}_{4}\right.$ and $\left.\mathrm{NH}_{4} \mathrm{NO}_{3}\right)$, $93 \mathrm{mg} \mathrm{K} \mathrm{kg}^{-1}\left(\mathrm{KH}_{2} \mathrm{PO}_{4}\right)$ and $73 \mathrm{mg} \mathrm{P} \mathrm{kg}^{-1}\left(\mathrm{KH}_{2} \mathrm{PO}_{4}\right)$, according to normal research practice with this kind of pots, soil and crop. The mass of soil added to each pot was equivalent to 9.5 and $8.5 \mathrm{~kg}$ for cmAR and crCM soils, respectively. On November 15th, fifty seeds of wheat ( $T$. aestivum L. var. Almansor) were sown in each pot, at $2 \mathrm{~cm}$ depth, and kept in a greenhouse, possessing environmental control, with day/night temperature of $25 / 8^{\circ} \mathrm{C}$, $12 \mathrm{~h}$ photoperiod, and $85 \%$ relative humidity. Distilled water was daily added to the pots to raise their moisture content to $70 \%$ of the soil water holding capacity, Seedlings were thinned to 25/pot two weeks after emergence. After 188 days, on May 23rd, the aerial portion of all plants was harvested, separated into grain and straw, weighed and oven-dried at $65^{\circ} \mathrm{C}$. The soil in each pot was air-dried, ground, sieved $(2 \mathrm{~mm})$ and analyzed as described below.

\subsection{Chemical analysis}

\subsubsection{Soil}

The organic carbon content of the soil was determined by dichromate oxidation (Nelson and Sommers, 1996); $\mathrm{pH}$ in 1:5 (w/v) soil/water mixtures; cation exchange capacity (CEC) (Mehlich, 1942); total nitrogen content by Kjeldahl method (Bremner and Mulvaney, 1982); mineral $\mathrm{N}$ as $\mathrm{N}-\mathrm{NH}_{4}^{+}$and $\mathrm{N}-\mathrm{NO}_{3}$ was extracted using $2 \mathrm{M} \mathrm{KCl}$ (Bremner, 1965) and measured with an autoanalyzer; and available P and K (Egner-Riehm) (Egner et al., 1960).

\subsubsection{Sludge}

Moisture content was calculated from weight loss after oven-drying to a constant weight at $105^{\circ} \mathrm{C}$; organic matter content by loss on ignition at $450^{\circ} \mathrm{C}$ for $4 \mathrm{~h}$ (Nelson and Sommers, 1996); total nitrogen content by Kjeldahl method (Bremner and Mulvaney, 1982). Total P, Na, Ca,
$\mathrm{Mg}, \mathrm{Fe}, \mathrm{Cu}, \mathrm{Mn}$, and $\mathrm{Zn}$ were determined after dry-ashing at $500{ }^{\circ} \mathrm{C}$ for $3 \mathrm{~h}$ (Richards, 1993).

\subsubsection{Plant tissue}

Dried samples were ground, dry-ashed at $500{ }^{\circ} \mathrm{C}$ for $4 \mathrm{~h}$, and analyzed as follows: $\mathrm{P}$ by the ammonium molybdateascorbic acid method (Murphy and Riley, 1962); N by Kjeldahl method (Bremner and Mulvaney, 1982); K and $\mathrm{Na}$ by flame photometer; $\mathrm{Ca}, \mathrm{Mg}, \mathrm{Fe}, \mathrm{Cu}, \mathrm{Mn}$, and $\mathrm{Zn}$ by atomic absorption spectrophotometry.

\subsection{Statistical analysis}

Soil and plant data were analyzed by analysis of variance (ANOVA) as a factorial completely randomized design. Mean values from the six replications for each property were tested a $P=0.05$ using Duncan's multiple range test (Steel and Torrie, 1980). Linear and quadratic regressions analysis was performed using SPSS system for windows, release 15.0 (SPSS, 2007).

\section{Results and discussion}

\subsection{Initial chemical characteristics}

\subsubsection{Soil}

Organic carbon content was low in both soils (5.42 and $3.10 \mathrm{~g} \mathrm{~kg}^{-1}$ Cambric arenosol and Cromic cambisol, respectively) as is typical for Mediterranean agricultural soils. The cmAR sandy soil is a medium $\mathrm{K}$ and $\mathrm{pH}$ and very low $\mathrm{P}$ soil, whereas the crCM sandy loam soil is a high $\mathrm{K}$, low $\mathrm{pH}$ and very low $\mathrm{P}$ soil (Table 1 ).

\subsubsection{Sludge}

The average moisture content of unamended SPS was $84 \%$ and the organic carbon content was $283 \mathrm{~g} \mathrm{~kg}^{-1}$ (Table 2). $\mathrm{N}, \mathrm{P}$, and $\mathrm{K}$ contents were $26.7,15.3$ and $0.9 \mathrm{~g} \mathrm{~kg}^{-1}$, respectively. The C:N and C:P ratios were 11 and 19 , respectively. Given the critical C:N ratio of 20-30 (Cordovil et al., 2007) and C:P ratio of 40-50 (Fageria et al., 2007) ready mobilization of $\mathrm{N}$ and $\mathrm{P}$ was to be expected when this sludge was added to the soils of the trial.

Another measure of suitability of organic residues as a nutrient source for plant growth is the ratio of the contents of $\mathrm{Ca}$ to $\mathrm{Mg}$. It is generally accepted that this ratio should be a minimum of 6:1 (Simard et al., 1998). The sludge used in this study had a $\mathrm{Ca}: \mathrm{Mg}$ ratio of $10: 1$, indicating that no adjustment by liming was needed. $\mathrm{Zn}$ and $\mathrm{Cu}$ contents were below concentration limits for unrestricted land application, which are designed to protect soil productivity, environmental quality and human health.

\subsection{Soil effects}

\subsubsection{Organic $C$}

Similar to reports of Battaglia et al. (2007), Cabral and Vasconcelos (1993), Levy and Taylor (2003) and Rotenberg 
Table 3

Effect of secondary paper mill sludge on selected chemical properties of amended soils

\begin{tabular}{|c|c|c|c|c|c|c|c|c|c|c|c|c|c|}
\hline \multirow[t]{3}{*}{ Properties } & \multirow[t]{3}{*}{ Unit } & \multicolumn{6}{|c|}{ cmAR soil } & \multicolumn{6}{|c|}{ crCM soil } \\
\hline & & \multicolumn{4}{|c|}{ SPS rate $\left(\mathrm{Mg} \mathrm{ha}^{-1}\right)$} & \multicolumn{2}{|l|}{ Response } & \multicolumn{4}{|c|}{ SPS rate $\left(\mathrm{Mg} \mathrm{ha}^{-1}\right)$} & \multicolumn{2}{|l|}{ Response } \\
\hline & & 0 & 40 & 80 & 120 & $\operatorname{Lin}^{A}$ & Quadratic $^{\mathrm{A}}$ & 0 & 40 & 80 & 120 & $\operatorname{Lin}^{\mathrm{A}}$ & Quadratic $^{\mathrm{A}}$ \\
\hline $\mathrm{OC}^{\mathrm{B}}$ & $\mathrm{g} \mathrm{kg}^{-1}$ & $5.40^{\mathrm{a}}$ & $5.80^{\mathrm{a}}$ & $6.00^{\mathrm{a}}$ & $6.70^{\mathrm{b}}$ & $0.947^{* *}$ & $0.972 \mathrm{NS}$ & $3.10^{\mathrm{a}}$ & $3.60^{\mathrm{a}}$ & $4.60^{b}$ & $5.30^{\mathrm{c}}$ & $0.927^{* *}$ & $0.967 \mathrm{NS}$ \\
\hline $\mathrm{pH}$ & & $6.40^{\mathrm{a}}$ & $7.37^{\mathrm{b}}$ & $7.37^{\mathrm{b}}$ & $7.60^{\mathrm{c}}$ & $0.770 \mathrm{NS}$ & $0.914 \mathrm{NS}$ & $5.10^{\mathrm{a}}$ & $6.70^{\mathrm{b}}$ & $7.23^{\mathrm{c}}$ & $7.33^{\mathrm{c}}$ & $0.927^{* *}$ & $0.992^{*}$ \\
\hline Available P & $\mathrm{mg} \mathrm{kg}^{-1}$ & $88.7^{\mathrm{a}}$ & $127.0^{\mathrm{b}}$ & $172.6^{\mathrm{c}}$ & $196.0^{\mathrm{d}}$ & $0.986^{* * *}$ & $0.994^{*}$ & $120.3^{\mathrm{a}}$ & $137.0^{\mathrm{b}}$ & $191.3^{\mathrm{c}}$ & $206.6^{\mathrm{d}}$ & $0.943^{* *}$ & $0.942 \mathrm{NS}$ \\
\hline Available K & $\mathrm{mg} \mathrm{kg}^{-1}$ & $47.3^{\mathrm{a}}$ & $57.3^{\mathrm{b}}$ & $58.7^{\mathrm{bc}}$ & $60.7^{\mathrm{c}}$ & $0.810^{*}$ & $0.960 \mathrm{NS}$ & $98.0^{\mathrm{a}}$ & $131.0^{\mathrm{b}}$ & $148.0^{\mathrm{c}}$ & $166.6^{\mathrm{d}}$ & $0.972^{* * *}$ & $0.992^{*}$ \\
\hline Inorganic $\mathrm{N}$ & $\mathrm{mg} \mathrm{kg}^{-1}$ & $2.33^{\mathrm{a}}$ & $2.77^{\mathrm{a}}$ & $6.44^{\mathrm{b}}$ & $5.72^{\mathrm{b}}$ & $0.747 \mathrm{NS}$ & $0.773 \mathrm{NS}$ & $3.91^{\mathrm{a}}$ & $3.68^{\mathrm{a}}$ & $7.09^{b}$ & $8.13^{\mathrm{b}}$ & $0.853^{*}$ & $0.881 \mathrm{NS}$ \\
\hline $\mathrm{Ca}$ & $\mathrm{cmol}_{\mathrm{c}} \mathrm{kg}^{-1}$ & $1.94^{\mathrm{a}}$ & $2.97^{\mathrm{b}}$ & $3.09^{\mathrm{b}}$ & $3.96^{\mathrm{c}}$ & $0.930^{* *}$ & $0.933 \mathrm{NS}$ & $3.52^{\mathrm{a}}$ & $4.86^{\mathrm{b}}$ & $5.19^{c}$ & $5.89^{d}$ & $0.933^{* *}$ & $0.966 \mathrm{NS}$ \\
\hline $\mathrm{Mg}$ & $\mathrm{cmol}_{\mathrm{c}} \mathrm{kg}^{-1}$ & $0.26^{\mathrm{a}}$ & $0.28^{\mathrm{b}}$ & $0.34^{\mathrm{c}}$ & $0.38^{\mathrm{d}}$ & $0.969^{* * *}$ & $0.980 \mathrm{NS}$ & $0.69^{c}$ & $0.61^{b}$ & $0.60^{\mathrm{b}}$ & $0.55^{\mathrm{a}}$ & $0.918^{* *}$ & $0.940 \mathrm{NS}$ \\
\hline $\mathrm{Na}$ & $\mathrm{cmol}_{\mathrm{c}} \mathrm{kg}^{-1}$ & $0.29^{\mathrm{a}}$ & $0.32^{\mathrm{a}}$ & $0.32^{\mathrm{a}}$ & $0.33^{\mathrm{a}}$ & $0.810^{*}$ & $0.911 \mathrm{NS}$ & $0.33^{\mathrm{a}}$ & $0.34^{\mathrm{a}}$ & $0.39^{\mathrm{b}}$ & $0.48^{\mathrm{c}}$ & $0.887^{*}$ & $0.999^{* * *}$ \\
\hline $\mathrm{K}$ & $\mathrm{cmol}_{\mathrm{c}} \mathrm{kg}^{-1}$ & $0.08^{\mathrm{a}}$ & $0.08^{\mathrm{a}}$ & $0.18^{\mathrm{a}}$ & $0.38^{\mathrm{b}}$ & $0.833^{*}$ & $0.998^{* * *}$ & $0.04^{\mathrm{a}}$ & $0.05^{\mathrm{ab}}$ & $0.05^{\mathrm{ab}}$ & $0.07^{\mathrm{b}}$ & $0.853^{*}$ & $0.904 \mathrm{NS}$ \\
\hline $\mathrm{Ca} / \mathrm{Mg}$ ratio & & 7.46 & 10.60 & 9.08 & 10.42 & $0.427 \mathrm{NS}$ & $0.524 \mathrm{NS}$ & 5.10 & 7.96 & 8.65 & 10.7 & $0.951^{* *}$ & $0.960 \mathrm{NS}$ \\
\hline $\mathrm{CEC}$ & $\mathrm{cmol}_{\mathrm{c}} \mathrm{kg}^{-1}$ & $4.26^{\mathrm{a}}$ & $4.28^{\mathrm{a}}$ & $4.20^{\mathrm{a}}$ & $5.00^{\mathrm{b}}$ & $0.533 \mathrm{NS}$ & $0.906 \mathrm{NS}$ & $7.32^{\mathrm{a}}$ & $8.53^{\mathrm{b}}$ & $8.40^{\mathrm{b}}$ & $8.53^{\mathrm{b}}$ & $0.593 \mathrm{NS}$ & $0.874 \mathrm{NS}$ \\
\hline $\mathrm{PBS}^{\mathrm{C}}$ & $\%$ & $63.2^{\mathrm{a}}$ & $86.5^{\mathrm{b}}$ & $92.3^{\mathrm{c}}$ & $98.7^{\mathrm{d}}$ & $0.877^{*}$ & $0.976 \mathrm{NS}$ & $62.5^{\mathrm{a}}$ & $68.7^{\mathrm{b}}$ & $73.5^{\mathrm{c}}$ & $81.6^{\mathrm{d}}$ & $0.990^{* * *}$ & $0.994^{*}$ \\
\hline
\end{tabular}

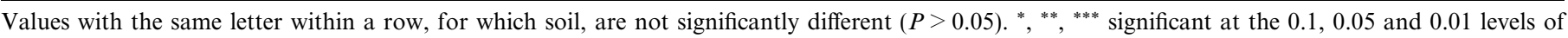
probability, respectively. NS = not significant.

A Values in these columns are the coefficients of determination $\left(r^{2}\right)$.

B $\mathrm{OC}=$ organic carbon content.

$\mathrm{C}$ PSB $=$ percent base saturation.

et al. (2005) the sludge increased the organic carbon content in both soils, although the differences were only statistically significant for the biggest sludge doses (Table 3 ). The average increase over the unamended pots was $0.4,0.6$ and $1.3 \mathrm{~g}$ organic $\mathrm{C} \mathrm{kg}^{-1}$ for $\mathrm{cmAR}$ soil and $0.1,1.1$ and $1.8 \mathrm{~g}$ organic $\mathrm{C} \mathrm{kg}^{-1}$ for $\mathrm{crCM}$ soil for the application of 40,80 and $120 \mathrm{Mg} \mathrm{ha}^{-1}$ of sludge, respectively.

\subsubsection{Inorganic $N$}

$\mathrm{N}$ content tended to increase with sludge rates (Table 3 ). As shown in Table 3, differences in total inorganic $\mathrm{N}$ after wheat harvest were significant between the 80 and $120 \mathrm{Mg} \mathrm{ha}^{-1}$ treatments and the other rates. Application of SPS significantly increased inorganic $\mathrm{N}$ of the $\mathrm{crCM}$ soil from 0 to $120 \mathrm{Mg} \mathrm{ha}^{-1}$ of sludge. However, in the cmAR soil inorganic $\mathrm{N}$ increased with increasing rate of SPS up to $80 \mathrm{Mg} \mathrm{ha}^{-1}$ and then decreased, although not significantly. This suggests that the $\mathrm{N}$-mineral fertilizer could have been immobilized during degradation of labile $\mathrm{C}$ constituents from SPS, and that the organic $\mathrm{N}$ mineralized very slowly when high levels of sludge were applied in cmAR soil.

Feldkinchner et al. (2003) and Vance (2000) have reported that amending soils with high $\mathrm{C}: \mathrm{N}$ pulp and paper mill sludge caused net immobilization of soil $\mathrm{N}$ and reduced plant growth. Conversely, low C:N sludges increased plant available $\mathrm{N}$ and biomass production in N-limited ecosystems (Cabral and Vasconcelos, 1993).

\subsection{3. $\mathrm{pH}$}

SPS application significantly also increased the $\mathrm{pH}$ in both soils (Table 3). Soils with high initial $\mathrm{pH}$ are expected to be more strongly buffered than soils with low $\mathrm{pH}$ (Tisdale and Nelson, 1998). In the acid crCM soil, sludge application rate was closely related to the change in soil $\mathrm{pH}$ and about $80 \mathrm{Mg} \mathrm{ha}^{-1}$ of SPS will be required to raise $\mathrm{pH}$ in crCM soil from 6.1 to 7.2. Our results are consistent with both, greenhouse cropping studies where a close relationship was reported between paper sludge application rate and $\mathrm{pH}$ in Mediterranean soils (Cabral and Vasconcelos, 1993), and with a field study in which paper mill sludge linearly increased soil $\mathrm{pH}$ more than one $\mathrm{pH}$ unit in a manufactured soil (Carpenter and Fernández, 2000).

\subsection{4. $\mathrm{Ca}$}

The Ca in the SPS (Table 2) is a combination of calcium carbonates, hydroxides and oxides reflecting the Kraft pulping process ingredients. Therefore, an increase in soil $\mathrm{pH}$ in both soils reflects the dissolution of these alkaline constituents in the sludge over experiment period. The liming effect of other types of paper sludges has been also observed by several researchers (Battaglia et al., 2007; Carpenter and Fernández, 2000).

\subsection{5. $P$}

Secondary paper mill sludge application linearly increased available $\mathrm{P}$ in selected soils (Table 3 ). The preapplication soil test levels in $\mathrm{cmAR}$ and $\mathrm{crCM}$ soil were very low and low, respectively, according to the Portugal recommendation guidelines (Santos, 2003). SPS application increased available $\mathrm{P}$ in cmAR soil from medium to high levels $\left(88-196 \mathrm{mg} \mathrm{kg}^{-1}\right)$ and from high to very high $\left(120-206 \mathrm{mg} \mathrm{kg}^{-1}\right)$ in crCM soil. Similarly, Simard et al. (1998) reported that de-inking paper sludge increased Mehlich-3 extractable $\mathrm{P}$ in soils from Canada. Other studies on similar Mediterranean soils (Cabral and Vasconcelos, 1993) have indicated that increasing amounts of combined primary/secondary pulp mill sludge did not cause any significative effect on available $\mathrm{P}$ due to the high $\mathrm{C}: \mathrm{P}$ ratio of the sludge used. However, in our study, an easy mobiliza- 
tion of $\mathrm{P}$ was expected when SPS was added to soil, due to the low C:P ratio of this sludge. The increase in extractable $\mathrm{P}$ in amended soils reflects the mineralization of organic $\mathrm{P}$ from the decomposition of SPS. However, increasing $\mathrm{pH}$ and $\mathrm{Ca}$ during experiment period may have limited this effect due to $\mathrm{P}$ fixation (Santos, 2003).

\subsubsection{Exchangeable $\mathrm{Ca}, \mathrm{K}, \mathrm{Na}$ and $\mathrm{Mg}$}

Application of SPS significantly increased exchangeable $\mathrm{Ca}, \mathrm{K}$ and $\mathrm{Na}$ in both soils. $\mathrm{Mg}$ significantly increased in cmAR soil and significantly decreased in crCM soil. These findings agree with other studies using similar materials. Simard et al. (1998) and Cabral and Vasconcelos (1993) reported that no consistent trend was observed for soil $\mathrm{Mg}$ as a function of increased paper sludge rates in soil. Sodium saturation in the amended soils was always higher than $5 \%$ of exchangeable $\mathrm{Na}$ percentage at which levels adverse impacts of $\mathrm{Na}$ can be evident (Cameron et al., 2003; Gilbert et al., 2007).

\subsubsection{Cation exchange capacity (CEC)}

With the exception of the $\mathrm{Mg}$ in crCM soil, there was a highly significant relationship between sludge application and all exchangeable cations in both soils, indicating that an increase in sludge rate resulted in a proportional increase in exchangeable basic cations in the soil. The net effect of the increase in exchangeable cations was the enrichment of soil exchange sites with basic cations in both soils. Quadratic regression, although not significant, gave the best fit for the SPS response curves in both soils, resulting $r^{2}$ values of 0.906 and 0.874 for cmAR and crCM soil, respectively (Table 3 ). As was expected, the increases in CEC are attributable to the increases in organic matter.

SPS application linearly decreased $\mathrm{Mg}$ saturation of the soil CEC from $10 \%$ to $7.5 \%$ in cmAR soil and for $15-7.8 \%$ in crCM soil (Table 3). It is generally accepted that $5 \%$ of $\mathrm{Mg}$ saturation is adequate for optimum yields of most crops. However, for those crops such as wheat, that requires a higher concentration of basic cations, $10 \% \mathrm{Mg}$ saturation is suggested to maintain the optimum $\mathrm{Mg}$ concentration in the plants, especially in the grain (Haby et al., 1990). Therefore, a wheat yield decrease, associated with an $\mathrm{Mg}$ deficiency, could be expected in amended cmAR soil and in amended crCM soil with a sludge rate higher than $40 \mathrm{Mg} \mathrm{ha}^{-1}$ (Table 3), if adequate $\mathrm{Mg}$ fertilizer is not provided. According with Carpenter and Fernández (2000) the high exchangeable Ca saturation percentage in amended soils, in combination with slightly alkaline soil $\mathrm{pH}$ values, corroborated the potential for $\mathrm{Mg}, \mathrm{Mn}, \mathrm{Cu}$ and $\mathrm{Zn}$ deficiencies in crops grown on these soils.

The percent base saturation of the nonamended soil was $63 \%$ and that of the soils receiving $120 \mathrm{Mg} \mathrm{ha}^{-1}$ sludge was $98 \%$ and $81 \%$ in cmAR and crCM soil, respectively. The ability of SPS to replace exchangeable cations and increase percent base saturation confirms its potential as a liming agent on Mediterranean acids soils.

\subsection{Plant effects}

SPS application linearly increased grain nitrogen content in plants grown in both soils (Fig. 1). Grain N content in soils amended with $120 \mathrm{Mg} \mathrm{ha}^{-1}$ of SPS were 1.2 and 1.3 times higher than the nonamended cmAR and crCM soils, confirming the soil inorganic $\mathrm{N}$ observations on increased soil $\mathrm{N}$ availability from SPS treatment. In contrast to $\mathrm{N}$, SPS had no effect on wheat grain $\mathrm{P}$ regardless of soil type (Table 4). This can be attributable to resorption or precipitation of soluble $\mathrm{P}$ released from SPS by Ca compounds, besides their interrelation with other nutrients. Similar to $\mathrm{P}$, SPS application did not affect $\mathrm{K}$ concentration of grain in cmAR soil (Table 4). However, SPS application altered significantly the concentration of $\mathrm{K}$ in grain of plant grown in crCM soil (Table 4). Application of SPS significantly increased $\mathrm{Ca}$ content in plants grown in both soils. Grain Ca was increased by $50 \%$ and $75 \%$ when $120 \mathrm{Mg} \mathrm{ha}^{-1}$ of SPS was applied to cmAR and crCM soil, respectively. Magnesium concentration of grain was not affected by SPS application in either soil (Table 4).

A highly significant inverse relationship between SPS rates and grain $\mathrm{Cu}$ content was observed in both soils. Grain $\mathrm{Cu}$ content was decreased by $83 \%$ and $61 \%$ when the highest rate of SPS was applied to cmAR and crCM soil, respectively. This was probably caused by a decrease in $\mathrm{Cu}$ availability as a result of an increase in soil $\mathrm{pH}$, in contribution to complexation with the organic matter. In addition, SPS application also decreased $\mathrm{Mn}$ and $\mathrm{Zn}$ concentration of grain in both soils. As was expected, the higher $\mathrm{Cu}, \mathrm{Mn}$ and $\mathrm{Zn}$ deficiencies occurred in the plant grown in the cmAR sandy soil. Therefore, $\mathrm{Cu}, \mathrm{Mn}$ and $\mathrm{Zn}$ uptake also could have restricted grain yield in this soil.

A highly significant inverse relationship between SPS application and wheat grain yield was also observed in cmAR soil (Table 4). A linear regression gave the best fit in cmAR soil while a quadratic regression gave the best fit for the SPS response curve in crCM soil (Fig. 2). Grain yields were reduced by $32 \%$ and $36 \%$ when $120 \mathrm{Mg} \mathrm{ha}^{-1}$ of SPS was applied to cmAR and crCM soil, respectively.

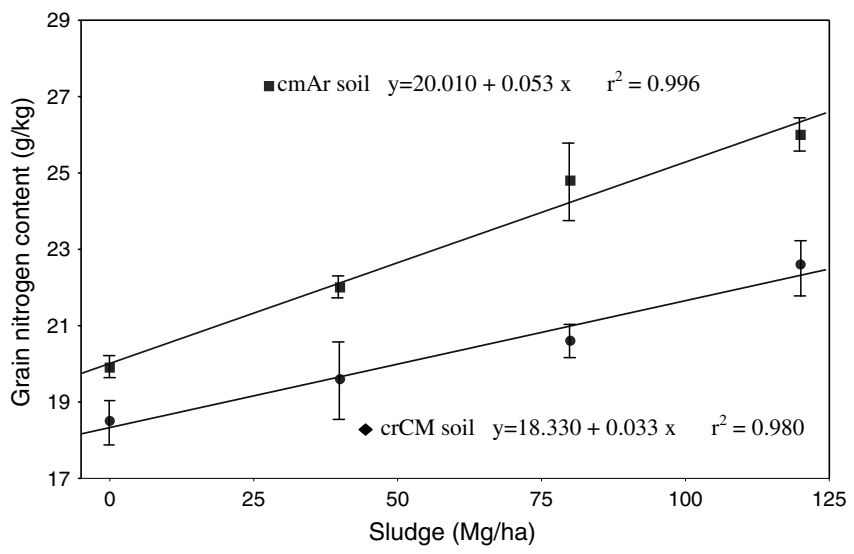

Fig. 1. Response of grain nitrogen of wheat grown in two Mediterranean soils amended with secondary paper sludge. 
Table 4

Wheat grain yield and selected elemental composition as affected by secondary paper mill sludge application

\begin{tabular}{|c|c|c|c|c|c|c|c|c|c|c|c|c|c|}
\hline & \multirow[t]{3}{*}{ Unit } & \multicolumn{6}{|c|}{ cmAR soil } & \multicolumn{6}{|c|}{ crCM soil } \\
\hline & & \multicolumn{4}{|c|}{ SPS rate $\left(\mathrm{Mg} \mathrm{ha}^{-1}\right)$} & \multicolumn{2}{|l|}{ Response } & \multicolumn{4}{|c|}{ SPS rate $\left(\mathrm{Mg} \mathrm{ha}^{-1}\right)$} & \multicolumn{2}{|l|}{ Response } \\
\hline & & 0 & 40 & 80 & 120 & $\operatorname{Lin}^{A}$ & Quadratic $^{\mathrm{A}}$ & 0 & 40 & 80 & 120 & $\operatorname{Lin}^{A}$ & Quadratic $^{\mathrm{A}}$ \\
\hline Yield & $\mathrm{g} \mathrm{pot}^{-1}$ & $42.7^{\mathrm{d}}$ & $36.1^{\mathrm{c}}$ & $32.7^{\mathrm{b}}$ & $28.7^{\mathrm{a}}$ & $0.977^{* * *}$ & $0.993^{*}$ & $24.6^{\mathrm{b}}$ & $37.1^{\mathrm{d}}$ & $29.8^{\mathrm{c}}$ & $15.5^{\mathrm{a}}$ & $0.242 \mathrm{NS}$ & $0.967 \mathrm{NS}$ \\
\hline $\mathrm{N}$ & $\mathrm{g} \mathrm{kg}^{-1}$ & $18.5^{\mathrm{a}}$ & $19.6^{\mathrm{b}}$ & $20.6^{\mathrm{c}}$ & $22.6^{\mathrm{c}}$ & $0.971^{* * *}$ & $0.993^{*}$ & $19.9^{\mathrm{a}}$ & $22.0^{\mathrm{b}}$ & $24.8^{\mathrm{c}}$ & $26.0^{\mathrm{d}}$ & $0.979^{* * *}$ & $0.988^{*}$ \\
\hline $\mathrm{P}$ & $\mathrm{g} \mathrm{kg}^{-1}$ & $3.70^{\mathrm{a}}$ & $3.0^{\mathrm{a}}$ & $3.4^{\mathrm{a}}$ & $3.4^{\mathrm{a}}$ & $0.051 \mathrm{NS}$ & $0.545 \mathrm{NS}$ & $3.2^{\mathrm{a}}$ & $3.2^{\mathrm{a}}$ & $3.6^{\mathrm{a}}$ & $3.5^{\mathrm{a}}$ & $0.663 \mathrm{NS}$ & $0.682 \mathrm{NS}$ \\
\hline $\mathrm{K}$ & $\mathrm{g} \mathrm{kg}^{-1}$ & $4.7^{\mathrm{a}}$ & $5.2^{\mathrm{a}}$ & $5.3^{\mathrm{a}}$ & $5.3^{\mathrm{a}}$ & $0.729 \mathrm{NS}$ & $0.982 \mathrm{NS}$ & $5.9^{\mathrm{b}}$ & $5.0^{\mathrm{ab}}$ & $5.3^{\mathrm{ab}}$ & $4.7^{\mathrm{a}}$ & $0.691 \mathrm{NS}$ & $0.720 \mathrm{NS}$ \\
\hline $\mathrm{Ca}$ & $\mathrm{g} \mathrm{kg}^{-1}$ & $0.4^{\mathrm{a}}$ & $0.5^{\mathrm{b}}$ & $0.6^{\mathrm{c}}$ & $0.6^{\mathrm{c}}$ & $0.891^{* *}$ & $0.982 \mathrm{NS}$ & $0.4^{\mathrm{a}}$ & $0.5^{\mathrm{b}}$ & $0.5^{\mathrm{b}}$ & $0.7^{\mathrm{c}}$ & $0.853^{*}$ & $0.905 \mathrm{NS}$ \\
\hline $\mathrm{Mg}$ & $\mathrm{g} \mathrm{kg}^{-1}$ & $0.9^{\mathrm{a}}$ & $0.9^{\mathrm{a}}$ & $1.1^{\mathrm{a}}$ & $1.1^{\mathrm{a}}$ & $0.800 \mathrm{NS}$ & $0.800 \mathrm{NS}$ & $1.3^{\mathrm{a}}$ & $1.2^{\mathrm{a}}$ & $1.4^{\mathrm{a}}$ & $1.2^{\mathrm{a}}$ & $0.018 \mathrm{NS}$ & $0.109 \mathrm{NS}$ \\
\hline $\mathrm{Na}$ & $\operatorname{mg~} 100 \mathrm{~g}^{-1}$ & $10.0^{\mathrm{a}}$ & $20.0^{\mathrm{a}}$ & $20.0^{\mathrm{a}}$ & $20.0^{\mathrm{a}}$ & $0.600 \mathrm{NS}$ & $0.933 \mathrm{NS}$ & $20.0^{\mathrm{a}}$ & $20.0^{\mathrm{a}}$ & $20.0^{\mathrm{a}}$ & $30.0^{\mathrm{a}}$ & $0.600 \mathrm{NS}$ & $0.933 \mathrm{NS}$ \\
\hline $\mathrm{Cu}$ & $\mathrm{mg} \mathrm{kg}^{-1}$ & $23.3^{\mathrm{a}}$ & $20.3^{b}$ & $4.7^{\mathrm{a}}$ & $4.7^{\mathrm{a}}$ & $0.859^{*}$ & $0.866 \mathrm{NS}$ & $25.0^{\mathrm{b}}$ & $13.7^{\mathrm{a}}$ & $17.3^{\mathrm{a}}$ & $9.7^{\mathrm{a}}$ & $0.705 \mathrm{NS}$ & $0.732 \mathrm{NS}$ \\
\hline $\mathrm{Mn}$ & $\mathrm{mg} \mathrm{kg}^{-1}$ & $52.3^{\mathrm{a}}$ & $22.7^{\mathrm{a}}$ & $20.7^{\mathrm{a}}$ & $21.0^{\mathrm{a}}$ & $0.643 \mathrm{NS}$ & $0.955 \mathrm{NS}$ & $81.0^{\mathrm{c}}$ & $34.7^{\mathrm{b}}$ & $25.7^{\mathrm{a}}$ & $24.7^{\mathrm{a}}$ & $0.740 \mathrm{NS}$ & $0.980 \mathrm{NS}$ \\
\hline $\mathrm{Zn}$ & $\mathrm{mg} \mathrm{kg}^{-1}$ & $30.3^{\mathrm{a}}$ & $24.0^{\mathrm{a}}$ & $26.3^{\mathrm{a}}$ & $26.0^{\mathrm{a}}$ & $0.269 \mathrm{NS}$ & $0.700 \mathrm{NS}$ & $37.0^{\mathrm{b}}$ & $31.7^{\mathrm{b}}$ & $32.0^{\mathrm{a}}$ & $29.7^{\mathrm{a}}$ & $0.806 \mathrm{NS}$ & $0.884 \mathrm{NS}$ \\
\hline
\end{tabular}

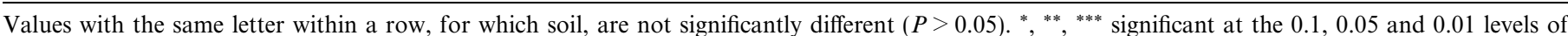
probability, respectively. NS = not significant.

A Values in these columns are the coefficients of determination $\left(r^{2}\right)$.

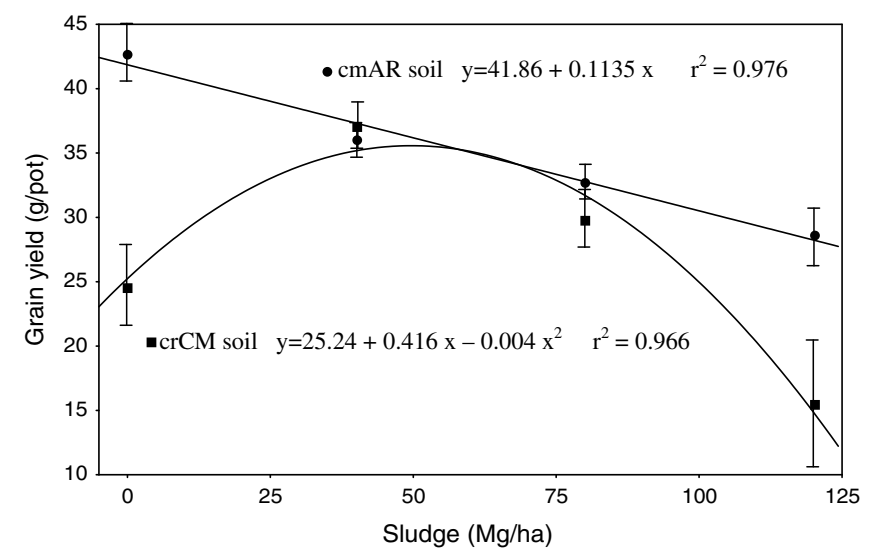

Fig. 2. Response of grain yield of wheat grown in two Mediterranean soils amended with secondary paper sludge.

Similar result was obtained by Singh et al. (2002). Nevertheless, the application of SPS at rate of $40 \mathrm{Mg} \mathrm{ha}^{-1}$ improved wheat yield in the acid crCM soil. This suggest that while small amounts of SPS applied to this kind of soil promote grain yield, a gradual reduction in this parameter was observed in proportion of the sludge applied to cmAR soil. Soil crCM had an initial low $\mathrm{pH}$ value and the liming capacity of the sludge may explain the favorable effect on yield when $40 \mathrm{Mg} \mathrm{ha}^{-1}$ of SPS was applied. Similar observations are reported by Simard et al. (1998) and Singh et al. (2002) in greenhouse and field conditions using other types of paper sludge.

The relationship between grain yield and SPS rate, together with the correlation shown between this sludge and $\mathrm{Mg}$ saturation, suggests that the decrease in grain yield was probably due to a reduction in soil $\mathrm{Mg}$ availability, caused by a $25 \%$ and $50 \%$ decrease in $\mathrm{Mg}$ saturation after SPS application in cmAR and crCM soil, respectively. It is well documented that Wheat grain is especially susceptible to $\mathrm{Mg}, \mathrm{Cu}, \mathrm{Mn}$ and $\mathrm{Zn}$ deficiencies, because these nutrients are vitals to the activation of some enzyme systems, which are related to grain formation in grain crops (Fageria et al., 2007; Liu and Wang, 2007; Santos, 2003).

The quadratic relationship between grain yield and $\mathrm{Mg}$ saturation (Table 4) accounted for more than $98 \%$ of the observed variation in crCM soil, indicating that grain yield of wheat grown in this soil was entirely dependent on the $\mathrm{Mg}$ availability and, therefore, $\mathrm{Mg}$ supplement to this soil treated with SPS could improve grain yield. Mg deficiency is also one of the major reasons for the observed grain yield decrease in cmAR soil. However, this fact alone does not explain the depressive effect on grain yield of wheat grown in this soil. The results reported in this work suggest that yield response in cmAR soil may be attributable to an $\mathrm{Mg}$ deficiency in contribution to lower availabilities of $\mathrm{Mn}, \mathrm{Cu}$ and $\mathrm{Zn}$ (Table 4). Moreover, imbalance between $\mathrm{Ca}$ and $\mathrm{Mg}$ in soils of low CEC could have accentuated these deficiencies.

The quadratic and linear regressions shown in Table 4 suggest that approximately $10 \%$ of $\mathrm{Mg}$ saturation is necessary to obtain the best grain yield in the wheat grown in both soils. This percentage is similar to that reported for grain crops by Haby et al. (1990). Because the selected soils are low in Mg saturation of soil CEC after SPS application, production of normal yields require the addition of $\mathrm{Mg}$ for proper nutrient balance.

The yield of straw, much lower in $\mathrm{Mg}$ requirements that wheat grain, improved significantly $(10 \%$ and $11 \%)$ when SPS, at rates of up to 120 and $80 \mathrm{Mg} \mathrm{ha}^{-1}$, was applied in cmAR and crCM soil, respectively (Table 5). SPS application linearly increased straw yield in cmAR soil. The percentage increase in straw yield was 3.6 to $11 \%$ greater than that achieved in untreated pots, with better growth at the highest SPS application rate. A significant curvilinear relationship between SPS application and wheat Straw yield was observed in $\mathrm{crCM}$ soil (Fig. 3). The highest yield was obtained with $80 \mathrm{Mg} \mathrm{ha}^{-1}$ rate of sludge. The other two rates of SPS had slightly lower yields but were significantly higher than the yield with fertilizer alone. 
Table 5

Wheat straw yield and selected elemental composition as affected by secondary paper mill sludge application

\begin{tabular}{|c|c|c|c|c|c|c|c|c|c|c|c|c|c|}
\hline & \multirow[t]{3}{*}{ Unit } & \multicolumn{6}{|c|}{ cmAR soil } & \multicolumn{6}{|c|}{ crCM soil } \\
\hline & & \multicolumn{4}{|c|}{ SPS rate $\left(\mathrm{Mg} \mathrm{ha}^{-1}\right)$} & \multicolumn{2}{|l|}{ Response } & \multicolumn{4}{|c|}{ SPS rate $\left(\mathrm{Mg} \mathrm{ha}^{-1}\right)$} & \multicolumn{2}{|l|}{ Response } \\
\hline & & 0 & 40 & 80 & 120 & $\operatorname{Lin}^{\mathrm{A}}$ & Quadratic $^{\mathrm{A}}$ & 0 & 40 & 80 & 120 & $\operatorname{Lin}^{\mathrm{A}}$ & Quadratic $^{\mathrm{A}}$ \\
\hline Yield & $\mathrm{g} \mathrm{pot}^{-1}$ & $57.9^{\mathrm{a}}$ & $60.0^{\mathrm{b}}$ & $60.3^{\mathrm{b}}$ & $64.3^{\mathrm{c}}$ & $0.887^{* *}$ & $0.929 \mathrm{NS}$ & $51.6^{\mathrm{a}}$ & $58.1^{\mathrm{b}}$ & $59.3^{\mathrm{b}}$ & $57.0^{\mathrm{b}}$ & $0.437 \mathrm{NS}$ & $0.995^{*}$ \\
\hline $\mathrm{N}$ & $\mathrm{g} \mathrm{kg}^{-1}$ & $6.2^{\mathrm{a}}$ & $8.7^{\mathrm{b}}$ & $9.9^{\mathrm{c}}$ & $11.1^{\mathrm{d}}$ & $0.961^{* *}$ & $0.994^{*}$ & $7.1^{\mathrm{a}}$ & $8.2^{\mathrm{b}}$ & $10.1^{\mathrm{c}}$ & $14.3^{\mathrm{d}}$ & $0.917^{* *}$ & $0.996^{* *}$ \\
\hline$P$ & $\mathrm{~g} \mathrm{~kg}^{-1}$ & $2.2^{\mathrm{a}}$ & $2.3^{\mathrm{a}}$ & $2.4^{\mathrm{a}}$ & $2.4^{\mathrm{a}}$ & $0.891^{* *}$ & $0.982 \mathrm{NS}$ & $0.8^{\mathrm{a}}$ & $1.8^{\mathrm{b}}$ & $2.4^{\mathrm{c}}$ & $3.1^{\mathrm{d}}$ & $0.988^{* * *}$ & $0.996^{* *}$ \\
\hline K & $\mathrm{g} \mathrm{kg}^{-1}$ & $6.6^{\mathrm{a}}$ & $8.2^{\mathrm{b}}$ & $6.7^{\mathrm{a}}$ & $7.4^{\mathrm{b}}$ & $0.025 \mathrm{NS}$ & $0.147 \mathrm{NS}$ & $7.5^{\mathrm{a}}$ & $7.7^{\mathrm{a}}$ & $10.9^{\mathrm{b}}$ & $12.5^{\mathrm{c}}$ & $0.915^{* *}$ & $0.942 \mathrm{NS}$ \\
\hline $\mathrm{Ca}$ & $\mathrm{g} \mathrm{kg}^{-1}$ & $6.6^{\mathrm{a}}$ & $6.9^{\mathrm{a}}$ & $6.9^{\mathrm{a}}$ & $7.4^{\mathrm{b}}$ & $0.873^{*}$ & $0.903 \mathrm{NS}$ & $6.9^{\mathrm{a}}$ & $7.1^{\mathrm{ab}}$ & $7.8^{\mathrm{b}}$ & $9.2^{\mathrm{c}}$ & $0.889^{* *}$ & $0.999^{* * *}$ \\
\hline $\mathrm{Mg}$ & $\mathrm{g} \mathrm{kg}^{-1}$ & $1.0^{\mathrm{a}}$ & $1.4^{\mathrm{b}}$ & $1.6^{\mathrm{c}}$ & $1.7^{\mathrm{c}}$ & $0.920^{* *}$ & $0.998^{* *}$ & $2.1^{\mathrm{a}}$ & $2.2^{\mathrm{a}}$ & $2.2^{\mathrm{a}}$ & $2.5^{\mathrm{b}}$ & $0.810^{*}$ & $0.911 \mathrm{NS}$ \\
\hline $\mathrm{Na}$ & $\mathrm{mg} 100 \mathrm{~g}^{-1}$ & $50.0^{\mathrm{a}}$ & $60.0^{\mathrm{a}}$ & $80.0^{\mathrm{b}}$ & $90.0^{\mathrm{b}}$ & $0.980^{* * *}$ & $0.980 \mathrm{NS}$ & $50.0^{\mathrm{a}}$ & $50.0^{\mathrm{a}}$ & $60.0^{\mathrm{ab}}$ & $70.0^{\mathrm{b}}$ & $0.891^{* *}$ & $0.982 \mathrm{NS}$ \\
\hline $\mathrm{Cu}$ & $\mathrm{mg} \mathrm{kg}^{-1}$ & $27.7^{\mathrm{a}}$ & $25.3^{\mathrm{a}}$ & $21.7^{\mathrm{a}}$ & $48.3^{\mathrm{a}}$ & $0.395 \mathrm{NS}$ & $0.885 \mathrm{NS}$ & $30.3^{\mathrm{a}}$ & $41.0^{\mathrm{a}}$ & $30.3^{\mathrm{a}}$ & $33.3^{\mathrm{a}}$ & $0.020 \mathrm{NS}$ & $0.195 \mathrm{NS}$ \\
\hline $\mathrm{Mn}$ & $\mathrm{mg} \mathrm{kg}^{-1}$ & $16.6^{\mathrm{a}}$ & $47.3^{\mathrm{b}}$ & $47.0^{\mathrm{b}}$ & $46.3^{\mathrm{b}}$ & $0.607 \mathrm{NS}$ & $0.934 \mathrm{NS}$ & $323.0^{\mathrm{d}}$ & $100.0^{\mathrm{c}}$ & $45.0^{\mathrm{a}}$ & $67.0^{\mathrm{b}}$ & $0.687 \mathrm{NS}$ & $0.992^{*}$ \\
\hline $\mathrm{Zn}$ & $\mathrm{mg} 100 \mathrm{~g}^{-1}$ & $21.5^{\mathrm{a}}$ & $21.6^{\mathrm{a}}$ & $14.8^{\mathrm{b}}$ & $14.5^{\mathrm{b}}$ & $0.811^{*}$ & $0.812 \mathrm{NS}$ & $16.4^{\mathrm{a}}$ & $17.7^{\mathrm{a}}$ & $14.9^{\mathrm{a}}$ & $19.8^{\mathrm{a}}$ & $0.212 \mathrm{NS}$ & $0.462 \mathrm{NS}$ \\
\hline
\end{tabular}

Values with the same letter within a row, for which soil, are not significantly different $(P>0.05) .{ }^{*},{ }^{* *},{ }^{* * *}$ significant at the $0.1,0.05$ and 0.01 levels of probability, respectively. NS = not significant.

${ }_{\mathrm{A}}$ Values in these columns are the coefficients of determination $\left(r^{2}\right)$.

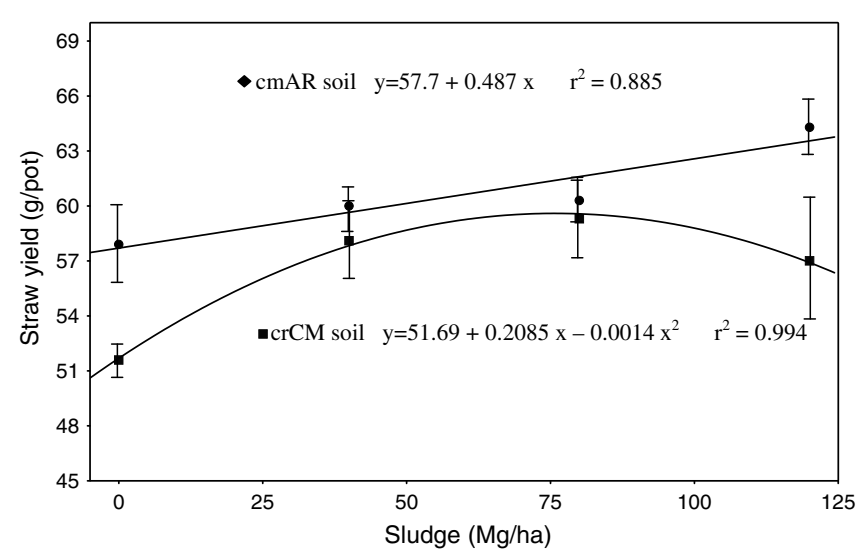

Fig. 3. Response of straw yield of wheat grown in two Mediterranean soils amended with secondary paper sludge.

Nitrogen concentration of wheat straw grown in nonamended cmAR and crCM soil was 6.2 and $7.1 \mathrm{~g} \mathrm{~kg}^{-1}$, respectively, and SPS application increased $\mathrm{N}$ concentration in plants grown in both soils (Table 5). At the highest rate of SPS the measured concentration of $\mathrm{N}$ in wheat straw grown in cmAR and crCM soils were 11.1 and $14.3 \mathrm{~g} \mathrm{~kg}^{-1}$, respectively. The straw seemed to contain sufficient $\mathrm{N}$ for normal growth. Nitrogen concentrations in plants in soil amended with $120 \mathrm{Mg} \mathrm{ha}^{-1}$ of SPS were 1.8 and 2.1 times higher than the nonamended cmAR and crCM soils, respectively. Applications of other types of sludge, such as de-inking paper sludge, have typically decreased plant N. Simard et al. (1998) reported that application of up to $45 \mathrm{Mg} \mathrm{ha}^{-1}$ of that sludge decreased $\mathrm{N}$ in barley tissues. In contrast, our data demonstrate that SPS could be a good source of $\mathrm{N}$ for plants.

Similar to N, SPS application affects K concentration of wheat straw. Potassium concentration in plants grown in soil amended with $120 \mathrm{Mg} \mathrm{ha}^{-1}$ of SPS was 1.2 and 1.7 times higher than the nonamended cmAR and crCM soils, respectively. Treatments also significantly affected $\mathrm{Na}$ in both soils. This is the result of the higher amounts of $\mathrm{Na}$ added with the sludge.In contrast to N and K, SPS application increased straw $\mathrm{P}$ of crCM soil but did not have any effect in plants grown in cmAR soil. Plant response to $\mathrm{P}$ from SPS application was expected in the low cmAR soil and very low $\mathrm{P}$ crCM soil but it only occurred in the very low $\mathrm{P}$ crCM soil, perhaps due to a higher precipitation of soluble P released from SPS by Ca compounds in cmAR soil. The lowest $\mathrm{pH}$ value on crCM soil can help to explain this result.

A highly significant inverse relationship between SPS application and straw Mn was observed in both soils and for $\mathrm{Zn}$ concentration in cmAR soil (Table 5). Lower availabilities of $\mathrm{Mn}$ and $\mathrm{Zn}$ are directly correlated with an increase of soil $\mathrm{pH}$. In addition, $\mathrm{Mn}$ and $\mathrm{Zn}$ deficiencies may result from an imbalance with other nutrients such as $\mathrm{Ca}$ and $\mathrm{Mg}$. Similar observations are reported by Vasconcelos and Cabral (1993) which reported that application of up to $130 \mathrm{Mg} \mathrm{ha}^{-1}$ of primary paper mill sludge to a Mediterranean Cambic arenosol decreased $\mathrm{Mn}$ and $\mathrm{Zn}$ in plants.

\section{Conclusions}

The results of this greenhouse study indicated that secondary paper mill sludge improved the properties of two Mediterranean soils. In particular, SPS lead to a significant increase in soil $\mathrm{pH}$ and organic matter content. This is of great interest in Mediterranean areas where acid soils poor in organic matter are quite frequent. Moreover, SPS increased plant growth. However, fertilizer, in particular additional $\mathrm{Mg}$, was required for optimal grain yield. Further studies are required to assess optimum sludge application and fertilizer rates in this type of soils.

\section{Acknowledgements}

The authors thank Dr. M.E. Collins and Dr. R. Kueh for their critical review of this manuscript. We are grateful 
to Dr. L. Cooperband for her helpful suggestions for improvements.

\section{References}

Battaglia, A., Calace, N., Nardi, E., Petronio, B., Pietroletti, M., 2007. Reduction of $\mathrm{Pb}$ and $\mathrm{Zn}$ bioavailable forms in metal polluted soils due to paper mill sludge addition. Effects on $\mathrm{Pb}$ and $\mathrm{Zn}$ transferability to barley. Bioresource Technol. 98, 2993-2999.

Bowie, S.H.U., Thornton, I., 1985. Environmental geochemistry and health. Kluver Academic Publ., Hingham, MA.

Bremner, J.M., 1965. Total nitrogen, inorganic forms of nitrogen. In: C.A. Black et al. (Eds.), Methods of Soil Analysis Part 2. Soil Science Society of America Special Publication No. 9, American Society of Agronomy, Madison, WI, pp. 1149-1255.

Bremner, J.M., Mulvaney, C.S., 1982. Nitrogen-Total. In: Page A.L. et al. (Eds.), Methods of Soil Analysis Part 2. Soil Science Society of America Special Publication No. 9, American Society of Agronomy, Madison, WI, pp. 595-624

Cabral, F., Vasconcelos, E., 1993. Agricultural use of combined primary/ secondary pulpmill sludge. Agrochimica 37, 409-417.

Calace, N., Campasi, T., Lancondini, A., Leoni, M., Petronio, B., Pietroletti, M., 2005. Metal-contaminated soil remediation by means of paper mill sludges addition: chemical and ecotoxicological evaluation. Environ. Pollut. 136 (3), 485-492.

Cameron, K.C., Di, H.J., Anwar, M.R., Russel, J.M., Barnett, J.W., 2003. The "critical" ESP value: does it change with land application of dairy factory effluent?. New Zealand Journal of Agricultural Research 46 $147-154$.

Carpenter, F., Fernández, I.J., 2000. Pulp sludge as a component in manufactured topsoil. J. Environ. Qual. 29, 387-397.

Cordovil, C., Cabral, F., Coutinho, J., 2007. Potencial mineralization of nitrogen from organic wastes to ryegrass and wheat crops. Bioresource Technol. 98 (17), 3265-3268.

Egner, H., Riehm, H., Domingo, W.R., 1960. Untersuchunen uber die chemishe boden-analyse als grundlage fur die beurteilung des nahrstoffzuntandes der boden. II. Chemische extraktions-methoden zur phosphor-und kalimbestimmung kungl. Lantbrukshoegsk. Ann. 26, 204-209.

Fageria, N.K., Baligar, V.C., Charles, A.J. 2007. Mineral Nutrition of Field Crops, second ed. CHIPS - Plant Science Handbook, p. 624

FAO, 2006. Soil map of the world. Revised leyend. World soil resources Report 60. FAO - Food and Agriculture Organization, Rome.

Feldkinchner, D., Wang, C., Gower, S., Kruger, E., Ferris, J., 2003. Effects of nutrient and paper mill biosolids amendment on growth and nutrient status of hardwood forest. Forest Ecol. Manag. 177, 95-116.

Foley, B., Cooperband, L., 2002. Paper mill residuals and compost effects on soil carbon and physical properties. J. Environ. Qual. 31, 20862095.

Gagnon, B., Lalande, R., Fahmy, 2001. Organic matter and aggregation in a degraded potato soil as effected by raw and composted pulp residue. Biol. Fert. Soils 34, 441-447.

Gilbert, P., Pilatti, M., Imhoff, S., Orellana, J., 2007. Hydraulic conductivity of molisols irrigated with sodic-bicarbonated waters. Agr. Water Manag. 88 (1-3), 192-200.

Haby, V.A., Russell, M.P., Skogley, E.O., 1990. Testing soils for potassium, calcium, magnesium. In: Westernman, R.L. (Ed.), Soil Testing and Plant Analysis, third ed. Soil Science Society of America, American Society of Agronomy, Madison, WI, pp. 181-227.

Leon, M., Stone, A., Dick, R., 2006. Organic soil amendments: impact on snap bean common root rot (Aphanomyes euteiches) and soil quality. Appl. Soil Ecol. 31 (3), 199-210.

Levy, J.S., Taylor, B.R., 2003. Effects of pulp mill solids and three composts on early growth of tomatoes. Bioresource Technol. 89 (3), 297-305.
Liu, Z., Wang, D., 2007. Phytase activity, phytate, iron, zinc contents in wheat pearling fractions and their variation across production location. J. Cereal Sci. 45 (3), 319-326.

Madrid, F., López, R., Cabrera, R., 2007. Metal accumulation in soil after application of municipal solid waste compost under intensive farming conditions. Agr. Ecosys. Environ. 199, 249-256.

Mahmood, T., Elliot, A., 2006. A review of secondary sludge reduction technology for the pulp and paper industry. Water Res. 40 (11), 2093 2112.

Mehlich, A., 1942. Rapid estimation of base-exchange properties of soils. Soil Sci. 53, 1-14.

Murphy, J., Riley, J.P., 1962. A modified single solution method for determination of phosphate in natural waters. Analítica Chimica Acta 27, 31-36.

Nelson, D.W., Sommers, L.E., 1996. Total carbon, organic carbon and organic matter. In: Sparks, D.L. (Ed.), Methods of Soil Analysis, Part 3. Soil Science Society of America, American Society of Agronomy, Madison, WI. pp. 961-1010.

Nunes, J.M., Cabral, F., López-Piñeiro, A., 2002. Semiarid agricultural soils response to application of secondary paper sludge. In: Ángel Faz, Roque Ortiz, Ahmet R. Mermut (Eds.), Sustainable Use and Management of Soils in Arid and Semiarid Regions. Vol II, International Symposium of Sustainable Use and Management of Soils in Arid and Semiarid Regions, Cartagena, Murcia, Spain, pp. 544-547.

Phillips, V.R., Kirkpatrick, N., Scotford, I.M., White, R.P., Burton, R.G., 1997. The use of paper-mill sludges on agricultural land. Bioresource Technol. 60, 73-80.

Pokhrel, D., Viraraghavan, T., 2004. Treatment of pulp and paper mill wastewater - a review. Sci. Total Environ. 333 (1-3), 37-58.

Richards, J.E., 1993. Chemical characterization of plant tissue. In: Carter, M.R. (Ed.), Soil Sampling and Methods of Analysis. Canadian Society of Soil Science. Lewis Publishers, Boca Raton, FL, pp. 115-119.

Rotenberg, D., Cooperband, L., Stone, A., 2005. Dynamic relationship between soil properties and foliar disease as effected by annual additions of organic amendment to a sandy soil vegetable production systems. Soil Biol. Biochem. 37 (7), 1343-1357.

Santos, J.Q., 2003. Fertilização-fundamentos da utilização de adubos e correctivos. Europa-America, Colecção Euroagro, Lisboa, p. 441.

Simard, R., Baziramakenga, R., Yelle, S., Coulombe, J., 1998. Effects of de-inking paper sludges on soil properties and crop yields. Canadian Journal of Soil Science 78, 689-697.

Singh, A., Agrawal, S., Rai, J., Singh, P., 2002. Assessment of pulp and paper mill effluent on growth, yield and nutrient quality of wheat (Triticum aestivum L.). Journal Environmental Biology 23 (3), 283 288.

SPSS (Statistical Package for the Social Science), 2007. SPSS Base 15.0 for Windows, User's Guide. SPSS Inc., Chicago, p. 736.

Steel, R.G., Torrie, J., 1980. Principles and Procedures of Statistics - A Biometrical Approach. McGraw-Hill Book Co., San Francisco, CA.

Tisdale, S.L., Nelson, W., 1998. Soil Fertility and Fertilizers, third ed. Macmillan, New York.

Tejada, M., Moreno, J., Hernandez, M., Garcia, C., 2007. Application of two beet vinasse forms in soil restoration: effects on soil properties in an arid environment in Southern Spain. Agr. Ecosys. Environ. 119, 289-298.

Vance, E., 2000. Utilizing paper mill by-products as forest amendment: forest responses, recommendations and industry case studies. Techinical Bulletin No. 798, NCASI.

Vasconcelos, E., Cabral, F., 1993. Use and environmental implications of pulp-mill sludge as an organic fertilizer. Environ. Pollut. 80, 159-162.

Wei, Y., Liu, Y., 2005. Effects of sewage sludge compost application on crops and cropland in a 3 years field study. Chemosphere 50, $1257-$ 1263.

Xiao, C., Bolton, R., Pan, W., 2007. Lignin from ric straw kraft pulping: effects on soil aggregation and chemical properties. Bioresource Technol. 98, 1482-1488. 